\title{
Parasites of dogs and cats imported to Iceland during 1989 - 2017 with remarks on parasites occurring in the native populations
}

\author{
KARL SKÍRNISSON, GUĐNÝ RUT PÁLSDÓTTIR AND MATTHÍAS EYDAL \\ Institute for Experimental Pathology at Keldur, University of Iceland, Keldnavegur 3, IS-112, Reykjavik, Iceland \\ E-mail:karlsk@hi.is,gudnyrut@hi.is,meydal@hi.is
}

\begin{abstract}
Importing dogs into Iceland was prohibited or restricted from 1909 until 1989, when the ban was lifted and importing dogs and cats permitted, with the proviso of an enforced period of quarantine and the requirement of specific medical treatments and examinations. Prior to importation pets must be treated against cestodes and external parasites. From 1989 until the end of 2017, a total of 3822 dogs and 900 cats were imported from 67 countries from all continents of the world, except Antarctica. Routine examinations for endoparasites revealed one or more species in $10.6 \%$ of the dogs and $4.2 \%$ of the cats. In spite of the required treatment, ectoparasites were detected on $0.2 \%$ of the dogs and $0.2 \%$ of the cats. Eighteen endoparasite species and six ectoparasite species have been identified from imported pets. Six species (one nematode, five ectoparasites) are believed to have been introduced to native dogs or cats with imported animals that were apparently still infected/ infested when they left quarantine and were handed over to the owners. Three of them are believed to have been eliminated after a temporary local occurrence, but two or three species of mites have become permanently resident.
\end{abstract}

Keywords: Dogs, cats, endoparasites, ectoparasites, import, quarantine, Iceland

\section{YFIRLIT}

Snikjudýr staðfest i innfluttum hundum og köttum á Íslandi á árunum 1989 - 2017 ásamt upplýsingum um snikjudýr sem fundist hafa i hundum og köttum innanlands

Innflutningur hunda til Íslands var bannaður nema með sérstakri undanpágu á árunum 1909 til 1989. Pá var banninu aflétt og innflutningur hunda og katta leyfður að uppfylltum skilyrðum um dvöl í einangrunarstöð, heilbrigðisskoðun og ákveðnar lyfjameðhöndlanir. Pá eru gerðar kröfur um lyfjameðhöndlun gegn bandormum og ytri sníkjudýrum fyrir komu dýranna til landsins. Frá 1989 fram til ársloka 2017 voru 3822 hundar og 900 kettir fluttir til landsins. Dýrin hafa komið frá 67 löndum í öllum heimsálfum. Leit að innsníklum leiddi í ljós eina eða fleiri tegundir sníkjudýra í 10,6\% hunda og 4,2\% katta, óværa hefur fundist við komuna til landsins á $0,2 \%$ hunda og 0,2\% katta. Alls hafa 18 tegundir innri sníkjudýra og sex tegundir óværu fundist í eða á innfluttum gæludýrum. Talið er að sex peirra (bráðormur og fimm óværutegundir) hafi borist yfir í innlenda hunda eða ketti með gæludýrum sem enn voru smituð pegar einangrunarvist lauk. Tvær eða prjár tegundanna virðast hafa náð fótfestu á Íslandi en talið er að tekist hafi að útrýma premur peirra.

\section{INTRODUCTION}

Import of dogs to Iceland was prohibited or restricted during 1909-1989, as a measure to prevent the reintroduction of the adult stage of the cestode Echinococcus granulosus, the 
causative agent of the widespread and serious hydatid disease that by the middle of the $19^{\text {th }}$ century was estimated to have infected more than every fifth human being in Iceland (Pálsson et al. 1953, Dungal 1957, Beard 1973, Pálsson 1984). During 1909-1989 relatively few dogs, only a few thousands, were estimated to live in the country. After increasing pressure from the Icelandic public the ban was lifted in 1989, with the proviso of an enforced period of quarantine and the requirement of specific medical treatments and examinations, both prior to the import into Iceland and during the quarantine period (MAST 2018, Eydal \& Skirnisson 2016). In 1989 importation of cats was also permitted, with the same conditions as approved for dogs. By the end of 2017, 28 years later, a total of 4722 dogs and cats originating from all continents of the world (except Antarctica) had been imported into Iceland. Throughout this period faecal samples from the imported animals were sent to the Laboratory of Parasitology at the Institute for Experimental Pathology at Keldur, University of Iceland (hereafter referred to as Keldur) where a systematic search for protozoan cysts and oocysts, and eggs and larvae of helminths, has been performed. Ectoparasites, occasionally detected on dogs and cats in quarantine in Iceland were sent to Keldur for species identification.

The aim of this article is to summarize which parasite species have been diagnosed in imported dogs and cats in quarantine and report the number of cases. Furthermore, a list of parasites of dogs and cats in Iceland was compiled. Special attention was paid to those parasite species that are believed to have been introduced into Iceland with the imported dogs and cats, pets that had already finished their mandatory stay in quarantine and had been delivered to the owners when the infection or infestation was diagnosed. Other known or suspected ways of parasite introduction are also discussed.

Previously, two comparable compilations have been performed. By December 1993, parasites identified from the first 133 dogs and 66 cats imported into Iceland had been evaluated (Richter et al. 1993), and seven years later a new compilation was carried out, in regard to the 608 dogs and 236 cats that had been imported before 2000 (Eydal et al. 2001).

\section{MATERIAL AND METHODS \\ Quarantine and duration of stay}

According to Icelandic legislation all imported dogs and cats must be quarantined. Since 1989 two quarantine stations have operated in Iceland, one in Hrísey, North Iceland (not operating in 2007, closed down in 2015) and another, still operating, was established in Hafnir, SW Iceland, in 2005. From 1989 to 2003 dogs and cats were kept in quarantine for 6-12 weeks, though since 2004 the quarantine period has been reduced to 4 weeks.

\section{Treatments of imported dogs and cats}

Ten days before import, dogs and cats must be treated against external parasites using an approved veterinary medical product and also against cestodes (Echinococcus spp.) using anticestodal drugs (MAST 2018). No specific treatment against nematodes is required. Anticestodal drugs are also effective against digeneans so that any digenean infections present should be eliminated.

In quarantine dogs and cats are treated against helminths and ectoparasites twice, first following arrival at the station, immediately after a faecal sample has been collected. The second treatment is performed at the end of the quarantine period, two days prior to delivery of the pet to its owner. The anthelmintic drug used at present is a combination of praziquantel, pyrantel and febantel (Prazitel Plus $\left.{ }^{\circledR}\right)$. In cases when Strongyloides stercoralis and Angiostrongylus vasorum (Figure 1) have been diagnosed, an additional anthelmintic treatment is performed. This includes one subcutaneous injection with ivermectin (Ivomec ${ }^{\circledR}$ ), followed by administering fenbendazole (Panacur $\AA$ ) for seven consecutive days. A combination of imidacloprid and moxidectin (Advocate $\AA$ ), (also an antinematodal drug) is used against ectoparasites. 

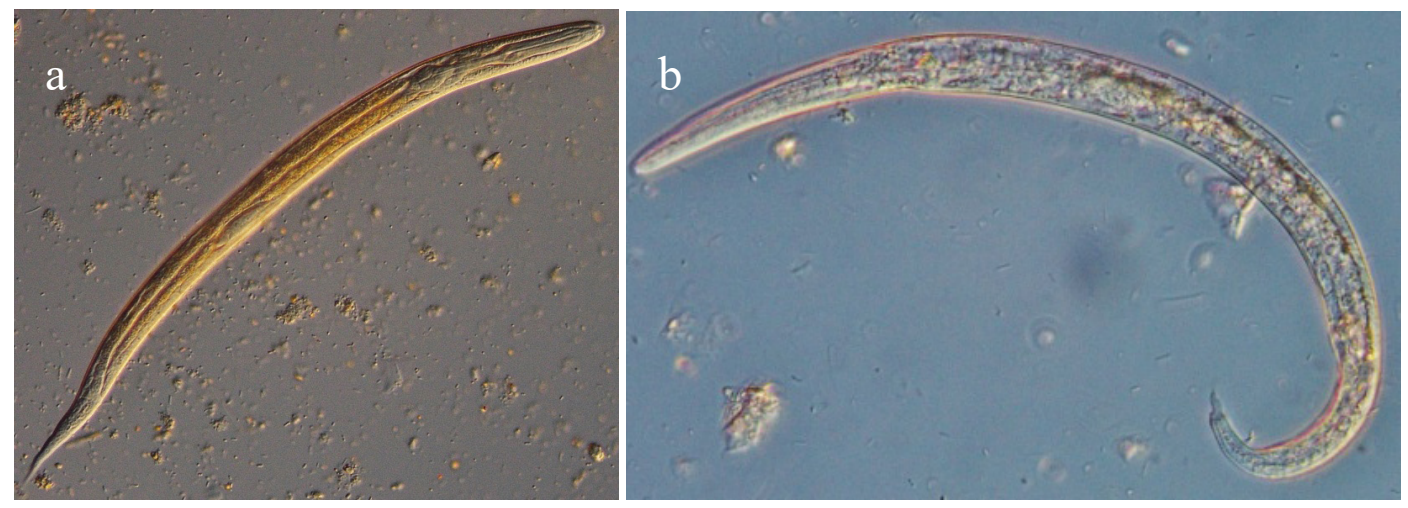

Figure 1. Light microscope photograph of two distinct first stage nematode larvae found in freshly passed dog faeces of imported dogs in quarantine in Iceland. a. Iodine-stained Strongyloides stercoralis larva, $371 \mu \mathrm{m}$ long. b. Unstained Angiostrongylus vasorum larva, $352 \mu \mathrm{m}$ long. Note the different tail shape.

\section{Diagnostic procedures}

In accordance with regulations issued by the Icelandic Food and Veterinary Authority, faecal samples from imported dogs and cats are subjected to examination for the presence of internal parasites. During 1989-2003 two faecal samples were examined from each imported animal, the first sample taken after arrival at the quarantine station before anthelmintic treatment and the second one taken at the end of the quarantine period, after the second treatment. After shortening the quarantine period to four weeks in 2004 a single faecal sample, taken prior to anthelmintic treatments, has been examined from each animal. At present, in cases where parasite species are found which are considered a potential threat to animal health (such as $S$. stercoralis and A. vasorum), a successful elimination of the parasite must be confirmed by examination of additional faecal samples.

All faecal samples collected in quarantine stations have been examined by using the formalin-ethyl acetate sedimentation technique (FEAST), a method used to concentrate protozoan cysts, coccidian oocysts, helminth eggs and larvae (Allen \& Ridley 1970, Young et al. 1979). For this purpose the Faecal Parasite Concentrator (FPC $\AA$ ) kit from Evergreen Scientific has been used. Since March 2012, all samples collected from dogs and cats in quarantine have also been examined using a modified Baermann technique, a method based on the description of Henriksen (1965) and explained in detail by Eydal \& Skirnisson (2016).

Ectoparasites are not systematically searched for on dogs and cats during the quarantine period. However, when occasionally detected, they are sent to Keldur for species identification.

\section{Parasite identification and photography}

Morphological identification of cysts, oocysts, eggs and larvae of dog and cat parasites (Figure 1, Figure 2) as well as ectoparasites (Figure 3) is based on a number of specific identification keys (e.g. Sloss 1972, Thienpoint et al. 1979, Anonymous 1986, Ash \& Orihel 1997) and various specific articles and textbooks (e.g. Soulsby 1965, Beaver et al. 1984, Miyazaki 1991, Rommel et al. 2000, Taylor et al. 2007, Bowman 2009).

Photographs of parasites were taken with digital cameras attached to a Leica DMLB microscope, equipped for differential interference contrast microscopy (DIC; Nomarski).

\section{RESULTS}

Imported dogs and cats and their geographical origin

From 1989 until December 2017, 3822 dogs and 900 cats were imported into Iceland through 


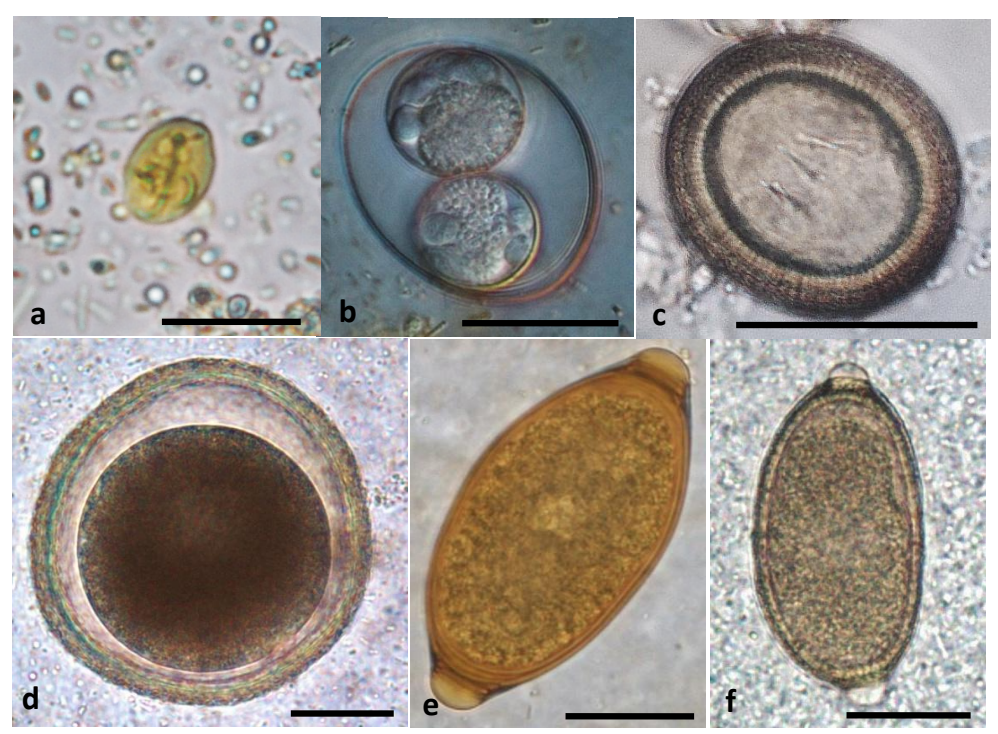

Figure 2. Light microscope photographs of iodine stained protozoan cyst, oocyst and four morphologically different helminth egg types (one cestode, three nematodes) in faecal samples from dogs or cats in Iceland. a. Mature cyst of $\mathrm{Gi}$ ardia duodenalis from a dog; b. Sporulated oocyst of Cystoisospora felis from a cat; c. Egg of Taenia ovis from a dog on an Icelandic farm; d. Toxocara canis egg from a dog; e. Egg of Trichuris vulpis from a dog; f. Egg of Eucoleus aerophilus from a dog. Scale bar: a. $15 \mu \mathrm{m}$, b-e. $25 \mu \mathrm{m}$.

quarantine stations. The animals came from 67 countries of the world. Almost $80 \%$ of the animals came from 38 countries in Europe; approximately half of them were imported from the neighbouring Nordic countries of Denmark, the Faroe Islands, Finland, Norway and Sweden. A total of $17 \%$ of imported dogs and cats came from North America (USA and Canada). The remaining dogs and cats (3\%) were imported from 12 countries in Asia (Afghanistan, China, Hong Kong, India, Israel, Japan, Kazakhstan, the Philippines, Lebanon, Singapore, Turkey and Thailand), 7 countries in Africa (Ghana, Kenya, Malawi, Mozambique, Namibia, South Africa

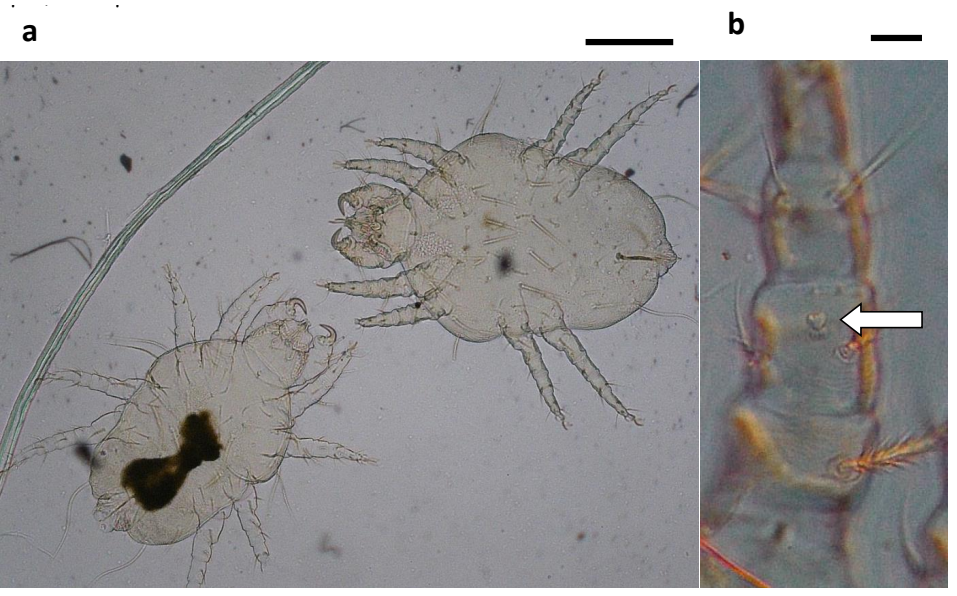

and Uganda), six in South and Central America (Argentina, Brazil, Chile, Cuba, Mexico and Panama), and two countries in Oceania (New Zealand and Australia).

\section{Number of parasite species}

At least 18 parasite species have been dignosed from imported dogs (Table 1) and 10 species have been dignosed from imported cats (Table 2). As Giardia duodenalis, Ancylostoma sp./ Uncinaria sp. and Toxascaris leonina were diagnosed both from dogs and cats, the total number of parasite species detected from pets in quarantines in Iceland is 24 .

Figure 3. Light microscope photograph of the dandruff mite Cheyletiella yasguri from a dog (boxer) in Iceland. a. Adult male (bottom left) and an adult female (top right). b. The heartsphaped sensory organ on genu I (white arrow) is characteristic of C. yasguri. Scale bar a. 100 $\mu \mathrm{m} ;$ b. $10 \mu \mathrm{m}$. 
Table 1. Parasites detected in samples from 3822 imported dogs kept in quarantine in Iceland during 1989 2017 with information and comments on their occurrence in Icelandic native dogs. $\mathrm{N}=$ number of infected dogs; Prev $=$ Prevalence of infection/infestation $(\%)$.

\begin{tabular}{|c|c|c|c|c|}
\hline Parasite & $\mathbf{n}$ & Prev & $\begin{array}{l}\text { Occurrence } \\
\text { in Iceland }\end{array}$ & Comments and references \\
\hline \multicolumn{5}{|l|}{ Protozoans } \\
\hline Giardia duodenalis & 164 & 4.3 & yes & $\begin{array}{l}\text { In native dogs (Ágústsson \& Richter 1993, Richter } \\
\text { et al. 1993) and some other hosts, e.g. ruminants }\end{array}$ \\
\hline Cystoisospora burrowsi & 7 & 0.2 & yes & In native dogs (unpubl. data) \\
\hline Cystoisospora ohioensis & 10 & 0.3 & yes & In native dogs (unpubl. data) \\
\hline Cystoisospora canis & 7 & 0.2 & yes & In native dogs (Richter et al. 1993, unpubl. data) \\
\hline Sarcocystis sp. & 4 & 0.1 & $?$ & $\begin{array}{l}\text { Unknown, may occur in native dogs in Iceland, } \\
\text { systematic search is lacking }\end{array}$ \\
\hline Digeneans & 3 & 0.1 & no & $\begin{array}{l}\text { Single, dead and empty Fasciola-sized eggs, } \\
\text { probably contamination from the food }\end{array}$ \\
\hline \multicolumn{5}{|l|}{ Nematodes } \\
\hline $\begin{array}{l}\text { Ancylostoma sp./Uncinaria } \\
\text { sp. }\end{array}$ & 23 & 0.6 & no/yes & $\begin{array}{l}\text { Uncinaria stenocephala has been reported from the } \\
\text { arctic fox (Skirnisson et al. 1993). }\end{array}$ \\
\hline Angiostrongylus vasorum & 1 & 0.03 & no & $\begin{array}{l}\text { The first case was identified in a dog in quarantine } \\
\text { in December } 2017\end{array}$ \\
\hline Eucoleus aerophilus & 3 & 0.1 & yes & $\begin{array}{l}\text { In the arctic fox (Skirnisson et al. 1993). Not } \\
\text { reported from dogs in Iceland. }\end{array}$ \\
\hline Toxocara canis & 102 & 2.7 & yes & $\begin{array}{l}\text { In native dogs (Krabbe 1865, Richter \& } \\
\text { Elmarsdóttir 1997) and the arctic fox (Skirnisson et } \\
\text { al. 1993) }\end{array}$ \\
\hline Toxascaris leonina & 21 & 0.5 & yes & $\begin{array}{l}\text { In native dogs (unpubl. data) and the arctic fox } \\
\text { (Skirnisson et al. 1993) }\end{array}$ \\
\hline Strongyloides stercoralis & 23 & 0.6 & no & $\begin{array}{l}\text { Occurred temporarily in native dogs (2012-2015), } \\
\text { introduced with a dog which had been quarantined } \\
\text { (Eydal \& Skirnisson 2016) }\end{array}$ \\
\hline Trichuris vulpis & 38 & 1.0 & no & Not reported from dogs in Iceland \\
\hline \multicolumn{5}{|l|}{ Mites } \\
\hline Otodectes cynotis & 1 & 0.03 & yes & $\begin{array}{l}\text { In native dogs (Lohse 2001), cats (Ágústsson \& } \\
\text { Richter 1993) and the arctic fox (Gunnarsson et al. } \\
\text { 1991) }\end{array}$ \\
\hline \multicolumn{5}{|l|}{ Ticks } \\
\hline Ixodes ricinus & 2 & 0.05 & $?$ & $\begin{array}{l}\text { Endemic status unknown, imported with migratory } \\
\text { birds in spring (Richter et al. 2013, Alfreðsson et al. } \\
\text { 2017) }\end{array}$ \\
\hline Rhipicephalus sanguineus & 3 & 0.1 & no & Sporadic cases known from Iceland in past decades \\
\hline \multicolumn{5}{|l|}{ Fleas } \\
\hline Ctenocephalides felis & 2 & 0.05 & no & $\begin{array}{l}\text { Not occurring in native dogs. Sporadic cases known } \\
\text { from Iceland in past decades (Skírnisson \& Richter } \\
\text { 1992, unpubl. data) }\end{array}$ \\
\hline Ctenocephalides canis & 1 & 0.03 & no & $\begin{array}{l}\text { Not occurring in native dogs. A single case reported } \\
\text { in } 2014\end{array}$ \\
\hline
\end{tabular}

\section{Parasites of imported dogs}

On average $10.7 \%$ of the 3822 imported dogs were infected with one, or on a few occasions, two or three parasite species. The most frequently reported endoparasite was the protozoan $G$. duodenalis, identified in $4.3 \%$ of the dogs, followed by several nematode species: Toxocara canis in $2.7 \%$, Trichuris vulpis 
(1.0\%), S. stercoralis (0.6\%), Ancylostoma sp. and/or Uncinaria sp. $(0.6 \%)$ and T. leonina $(0.5 \%)$ (Table 1). Cystoisospora ohioensis was detected in $0.3 \%$, Cystoisospora burrowsi and Cystoisospora canis occurred in $0.2 \%$, Sarcocystis sp. and Eucoleus aerophilus in $0.1 \%$ of the dogs. The heartworm A. vasorum was found for the first time in Iceland in a dog imported from Switzerland in December 2017. Single Fasciola-sized, large digenean eggs were found in samples from three dogs, but as the eggs were empty and without formed contents, they were not considered a sign of active infection.

Nine dogs were found to be infested with ectoparasites upon arrival in quarantine (Table 1). Three had the brown dog tick Rhipicephalus sanguineus, two had the tick Ixodes ricinus, two hosted cat fleas Ctenocephalides felis, one had the ear canker mite Otodectes cynotis, and one had the dog flea Ctenocephalides canis (Table $1)$.

\section{Parasites of imported cats}

On average $4.4 \%$ of the 900 imported cats were infected with a parasite, though double infections were never detected. The most frequently reported parasite was the protozoan $G$. duodenalis (infection prevalence 1.2\%), followed by the coccidian Cystoisospora felis (1.1\%), the cat ascarids Toxocara cati $(1.0 \%)$ and T. leonina (0.3\%). The nematodes Ancylostoma $\mathrm{sp} . /$ Uncinaria sp. were found in two cats $(0.2 \%)$ (Table 2$)$. One cat was infected with the coccidian Cystoisospora rivolta, another with the cat cestode Taenia taeniaeformis, and one had the digenean Opistorchis felineus (Table $2)$. Two cats were found to be infested with an ectoparasite, one hosted the cat flea C. felis,

Table 2. Parasites detected in samples from 900 imported cats kept in quarantine in Iceland during 1989 - 2017 with information and comments on their occurrence in Icelandic native cats. $\mathrm{N}=$ number of infected cats; Prev $=$ Prevalence of infection/infestation (\%).

\begin{tabular}{|c|c|c|c|c|}
\hline Parasite & $\mathbf{n}$ & Prev & $\begin{array}{l}\text { Occurrence } \\
\text { in Iceland }\end{array}$ & Comments and references \\
\hline \multicolumn{5}{|l|}{ Protozoans } \\
\hline Giardia duodenalis & 11 & 1.2 & yes & $\begin{array}{l}\text { In native cats (Ágústsson \& Richter 1993, Smáradóttir \& } \\
\text { Skírnisson 1996) and many other hosts }\end{array}$ \\
\hline Cystoisospora felis & 10 & 1.1 & yes & $\begin{array}{l}\text { In native cats (Ágústsson \& Richter 1993, Richter et al. } \\
\text { 1993) }\end{array}$ \\
\hline Cystoisospora rivolta & 1 & 0.1 & no & Identified once in an imported cat \\
\hline \multicolumn{5}{|l|}{ Digeneans } \\
\hline Opistorchis felineus & 1 & 0.1 & no & Identified once in an imported cat \\
\hline \multicolumn{5}{|l|}{ Cestodes } \\
\hline Taenia taeniaeformis & 1 & 0.1 & yes & In native cats (Krabbe 1865, Skirnisson 2017) \\
\hline \multicolumn{5}{|l|}{ Nematodes } \\
\hline $\begin{array}{l}\text { Ancylostoma sp./ } \\
\text { Uncinaria sp. }\end{array}$ & 2 & 0.2 & no & Never reported from cats in Iceland \\
\hline Toxocara cati & 9 & 1.0 & yes & $\begin{array}{l}\text { In native cats (Krabbe 1865, Ágústsson \& Richter 1993, } \\
\text { Smáradóttir \& Skírnisson 1996) }\end{array}$ \\
\hline Toxascaris leonina & 3 & 0.3 & yes & $\begin{array}{l}\text { In native cats (Smáradóttir \& Skírnisson 1996), dogs and } \\
\text { the arctic fox (Skirnisson et al. 1993) }\end{array}$ \\
\hline \multicolumn{5}{|l|}{ Mites } \\
\hline Dermanyssus gallinae & 1 & 0.1 & yes & $\begin{array}{l}\text { Occasional finding. Reported on native domestic chicken } \\
\text { (Skirnisson 2017b) }\end{array}$ \\
\hline \multicolumn{5}{|l|}{ Fleas } \\
\hline Ctenocephalides felis & 1 & 0.1 & no & Identified once on an imported cat \\
\hline
\end{tabular}


and another had the chicken mite Dermanyssus gallinae.

\section{Parasites of native dogs}

Altogether 24 parasite species have been reported from dogs in Iceland (Table 3); 15 of these belong to the category native species (parasites that are considered to occur in dogs in Iceland at present), four are cestodes that have already been eradicated in Iceland (species that were found all over Iceland in past centuries), and five species (four ectoparasites and the nematode S. stercoralis) temporarily occurred in Iceland in recent decades, but are believed to have been eradicated at the present time (see below).

At present three mite species are reported to occur occasionally on dogs in Iceland: the dandruff mite Cheyletiella yasguri, the follicular mange mite Demodex canis, and the nasal mite Pneumonyssoides caninum. All three are believed to have unintentionally been introduced into the native dog population with dogs that are considered to have still been infested after finishing the required quarantine period and after having been delivered to the owners. The mallophagan dog louse Trichodectes canis was probably also introduced into Iceland in this way but is believed to have been eradicated in Iceland after a few years of restricted occurrence. Three further ectoparasites (Linognatus setosus, $R$. sanguineus and $C$. felis) are also regarded to have temporarily occurred locally before being eradicated in Iceland. O. cynotis, however, is a well-known parasite of cats, dogs and the arctic fox Vulpes lagopus, and I. ricinus is imported every spring with migratory birds and regularily detected on outdoor dogs and cats.

\section{Parasites of native cats}

A total of 13 parasite species have been reported from cats in Iceland (Table 4). Ten are considered to be native, whereas three are ectoparasites that are believed to have been eradicated after a temporary occurrence. These are the mite Cheyletiella blakei that was found to infest Persian cats in the mid 1990s, the mallophagan cat louse Felicola subrostratus, and the cat flea C. felis.

\section{DISCUSSION}

\section{Previous surveys}

From 1863 - 1970 quite extensive research on helminth infections of dogs and cats in Iceland, mainly cestode infections, was performed by post mortem examinations (Krabbe 1865, Pálsson 1984, Pálsson et al. 1953, 1971). Four of the cestode species which previously infected dogs in Iceland (Table 3 ) have been eradicated (Skirnisson 2017a).

In recent decades knowledge on endoparasites of dogs and cats in Iceland has mainly been collected by examination of faecal samples. The most recent survey was performed during 2012 - 2015 when faecal samples from 96 native dogs were examined, mainly for the presence of the newly introduced nematode $S$. stercoralis (Figure 1). In most cases the Baermann technique was used, though sometimes also the FEAST method (Eydal \& Skirnisson 2016). In the 1990s three other studies were carried out: Richter \& Elmarsdóttir (1997) examined faecal samples from 115 dogs with the FEAST method, Ágústsson \& Richter (1993) used the same method to examine faecal samples from 64 cats, they also searched for helminths in the intestines of 30 cats. The third survey was carried out in 1995 when cat faeces, as well as several faecal samples from dogs, were collected from 32 sandpits in the Reykjavík area and examined for the presence of parasites (Smáradóttir \& Skirnisson 1996). In addition to these surveys, dozens of faecal samples, collected from dogs and cats in different parts of the country in past decades, have been submitted to Keldur for parasitological examination. Endoparasites detected in the these studies are compiled in Tables $3 \& 4$. Information on ectoparasite infestations of Icelandic dogs and cats is mainly based on examinations of samples that dog and cat owners, practicing veterinarians and veterinarians working for the Icelandic Food and Veterinary Authority (MAST), formerly the Chief Veterinary Office, have sent in to Keldur for identification. Such identifications have been performed at Keldur since the early 1970s. Further research is needed to reveal the current diversity of parasites in native pets. 
Table 3. Present status of 24 parasite species reported in the past from dogs in Iceland with comments on their occurrence. The 15 parasite species currently occurring are defined as "native", four eradicated cestode species, which were common in Iceland for centuries, are defined as "eradicated", and five species that occurred temporarily locally (for months or a few years) are defined as "temp occ".

\begin{tabular}{|c|c|c|}
\hline Parasite & Status & Comments and references \\
\hline \multicolumn{3}{|l|}{ Protozoans } \\
\hline Giardia duodenalis & native & $\begin{array}{l}\text { Reported from dogs (Ágústsson \& Richter 1993, Richter et al. 1993) and many } \\
\text { other hosts }\end{array}$ \\
\hline Cystoisospora burrowsi & native & Host-specific in dogs (unpubl. data) \\
\hline Cystoisospora canis & native & Host-specific in dogs (Richter et al. 1993, unpubl. data) \\
\hline Cystoisospora ohioensis & native & Host-specific in dogs (unpubl. data) \\
\hline \multicolumn{3}{|l|}{ Cestodes } \\
\hline $\begin{array}{l}\text { Diphyllobothrium } \\
\text { dendriticum }\end{array}$ & native & $\begin{array}{l}\text { Usually in fish-eating wild birds and mammals (Krabbe 1865, Eydal 1992a } \\
\text { Skírnisson 2017) }\end{array}$ \\
\hline Diphyllobothrium ditremum & native & $\begin{array}{l}\text { Usually in fish-eating wild birds and mammals (Krabbe 1865, Eydal 1992a } \\
\text { Skírnisson 2017) }\end{array}$ \\
\hline Dipylidium caninum & eradicated & Eradicated decades ago (Krabbe 1865, Pálsson et al. 1971, Skirnisson 2017) \\
\hline Echinococcus granulosus & eradicated & Eradicated decades ago (Krabbe 1865, Davidson et al., 2016, Skirnisson 2017) \\
\hline $\begin{array}{l}\text { Mesocestoides } \\
\text { canislagopodis }\end{array}$ & native & $\begin{array}{l}\text { Common in the arctic fox (Skirnisson et al. 1993, Skirnisson et al. 2016), } \\
\text { reported from cats (Krabbe 1865, Skírnisson 2017) }\end{array}$ \\
\hline Taenia hydatigena & eradicated & $\begin{array}{l}\text { Reported last in sheep in } 2008 \text { (Krabbe 1865, Pálsson et al. 1971, Skirnisson } \\
\text { 2017) }\end{array}$ \\
\hline Taenia multiceps & eradicated & Eradicated decades ago (Krabbe 1865, Skirnisson 2017) \\
\hline Taenia ovis & native & $\begin{array}{l}\text { First detected in sheep } 1983 \text { (Richter et al. 1984, 1987) and in a dog } 2016 \\
\text { (Eydal \& Jörundsson 2017, Skirnisson 2017) }\end{array}$ \\
\hline
\end{tabular}

Nematoda

Strongyloides stercoralis

Toxocara canis

Toxascaris leonina

temp occ Temporary occurrence (2008-2015). Introduced with a dog through quarantine (Eydal \& Skirnisson 2016)

native In dogs (Krabbe 1865, Richter \& Elmarsdóttir 1997, Smáradóttir \& Skírnisson 1996) and the arctic fox (Skirnisson et al. 1993)

native In dogs (unpubl. data) and the arctic fox (Skirnisson et al. 1993)

Mites

Cheyletiella yasguri

native Believed to have been introduced with a dog after being quarantined in the 1990s (Skirnisson et al. 1997)

Demodex canis

native Believed to have been introduced with a dog after being quarantined in the 1990s (Skirnisson \& Finnsdóttir 1993)

Otodectes cynotis

Pneumonyssoides caninum

native In dogs (Lohse 2001), cats (Ágústsson \& Richter 1993) and the arctic fox (Gunnarsson et al. 1991) native Believed to have been introduced with a dog after being quarantined (unpubl. data)

Ticks

Rhipicephalus sanguineus*

Ixodes ricinus

emp occ Sporadic cases confirmed in past decades (Skírnisson \& Eydal 2008, unpubl. data)

native Imported with migratory birds every spring (Richter 1981, Richter et al. 2013, Alfreðsson et al. 2017)

Lice

Trichodectes canis

Linognathus setosus*

temp occ Occurred locally in the early 1990s, probably introduced with a dog after being quarantined (Richter et al. 1993)

Fleas

Ctenocephalides felis ${ }^{*} \quad$ temp occ Sporadic cases identified in past decades (Skírnisson \& Richter 1992, unpubl. data)

${ }^{*}$ The parasite is believed to have been introduced in some cases in the luggage of travelling people 
Parasites of dogs and cats in Iceland

Fifteen parasite species are considered to be currently present in dogs in Iceland (Table 3), and 10 species are thought to infect/infest cats (Table 4). However, further species, not yet verified in native dogs and cats, are likely to be present in Iceland. For example, protozoans of the genus Cryptosporidium, which are common in dogs worldwide and confirmed from various mammals in Iceland, e.g. from cats (Eydal et al. 1990), have never been identified from native dogs. The same applies to Sarcocystis spp., a parasite having a worldwide occurrence in dogs and cats. A number of Sarcocystis species are known to use dogs or cats as final hosts and farm animals (sheep, goats, cattle) as intermediate hosts (Rommel 2000). Thus, for example, cats are the final hosts of Sarcocystis

Table 4. Present status of 13 parasite species reported in the past from cats in Iceland with comments on their occurrence. Currently occurring parasites (10 species) are defined as "native"; three species that have temporarily occurred locally (for months or a few years) before eradication in Iceland are defined as "temp occ".

\begin{tabular}{lrl}
\hline Parasite & Status & Comments and references \\
\hline Protozoans & native & $\begin{array}{l}\text { In cats (Ágústsson \& Richter 1993, Smáradóttir \& Skírnisson } \\
\text { 1996) and many other hosts }\end{array}$ \\
Gryptia duodenalis & native & $\begin{array}{l}\text { In cats (Eydal et al. 1990, Skírnisson et al. 1993, Smáradóttir \& } \\
\text { Skírnisson 1996) and many other hosts }\end{array}$ \\
Toxoplasma gondii & native & $\begin{array}{l}\text { Host-specific in cats (Smáradóttir \& Skírnisson 1996, Finnsdóttir } \\
1997)\end{array}$ \\
Cystoisospora felis & native & $\begin{array}{l}\text { Host-specific in cats (Ágústsson \& Richter 1993, Richter et al. } \\
1993)\end{array}$
\end{tabular}

Cestodes

Mesocestoides canislagopodis

Taenia taeniaeformis

Nematoda

Toxocara cati

Toxascaris leonina

Mites

Cheyletiella blakei

Otodectes cynotis

Ticks

Ixodes ricinus

Lice

Felicola subrostratus

Fleas

Ctenocephalides felis* native In cats (Krabbe 1865), dogs (Krabbe 1865, Ágústsson \& Richter 1993) and the arctic fox (Skirnisson et al. 1993, Skirnisson et al. 2016)

native Host-specific in cats (Krabbe 1865, Skirnisson 2017)

native Host-specific in cats (Krabbe 1865, Ágústsson \& Richter 1993, Smáradóttir \& Skírnisson 1996)

native In cats (Smáradóttir \& Skírnisson 1996), dogs (unpublished) and the arctic fox (Skirnisson et al. 1993)

temp occ Believed to have been introduced with a persian cat after being quarantined in the 1990s (Skírnisson et al. 1997) but soon eradicated

native On cats (Skirnisson \& Richter 1992, Ágústsson \& Richter 1993), dogs (Lohse 2001) and the arctic fox (Gunnarsson et al. 1991)

native Imported with migratory birds every spring (Richter 1981, Richter et al. 2013, Alfreðsson et al. 2017)

temp occ Occasionally reported some decades ago (Skirnisson \& Richter 1992, Ágústsson \& Richter 1993), believed to have been eliminated

temp occ Sporadic cases known in past decades (Skirnisson \& Richter 1992, unpubl. data)

*The parasite is believed to have been introduced in some cases in the luggage of travelling people 
gigantea, a species that is occasionally noticed macroscopically in the oesophagus of sheep in Iceland. Other Sarcocystis species are known to have cats and dogs as final hosts (Rommel 2000), but whether they occur in Iceland is unknown. Also, the nematodes E. aerophilus and Uncinaria stenocephala, both confirmed to infect the arctic fox in Iceland (Skirnisson et al. 1993), might occasionally infect dogs in the country. Furthermore, several endemic bloodsucking ectoparasites (ticks, blackflies, lousefly, distinct bird and rodent fleas) that occasionally suck blood from dogs and cats, are lacking on the lists presented in Tables $3 \& 4$.

In Central Europe approximately 100 and 75 species have been reported to parasitize dogs and cats, respectively (Rommel et al. 2000). It is stressed that these numbers are more then five times higher than those reported above for dogs and cats in Iceland.

\section{Further parasites might be expected in imported pets}

The wide-ranging geographical origin of dogs and cats imported into Iceland - 67 countries in all continents except Antarctica, more than one third of the 193 member states of the United Nations - underlines the fact that almost any species of the world fauna of dog and cat parasites might be expected to be brought with pets on arrival in quarantine stations in Iceland. Actually, a specific diagnosis for many of these parasites is not routinely performed in Iceland. For example, blood samples are not examined for the presence of parasites (e.g. microfilariae of Dirofilaria spp., protozoans such as Babesia, Hepatozoon, Trypanosoma and Leishmania), parasites that need various bloodsucking vectors for their transmission. But as most of these vectors do not occur in Iceland a transmission of these parasites is considered to be impossible.

No information is available on haematozoan infections that might have been brought to Iceland. The same applies to many other parasites. No routine examinations are made, for example, on parasites that might be detected in the urine of the hosts (Dichtophyma renale,
Capillaria plica), species that live in the intraperitoneal cavity (e.g. tetrathyridia of Mesocestoides sp.) or must be searched for in specific tissues (Trichinella spp.) or in skin and connective tissues (Taenia serialis, Dracunculus sp., Dirofilaria repens, Acanthocheilonema sp.) (Rommel et al. 2000, Barr \& Bowman 2012, ESCCAP 2017).

\section{Parasites introduced into Iceland with imported pets}

In spite of the demanded antiparasitic treatments of imported dogs and cats, six parasite species (five ectoparasites, one nematode) are believed to have been introduced into Iceland with quarantinized dogs or cats. Three of these species are believed to be now permanently present in Iceland (D. canis, P. caninum and C. yasguri in dogs). The other three, C. blakei in cats and T. canis and S. stercoralis in dogs, had a temporary, local occurrence in Iceland prior to a successful eradication. In four cases (D. canis, C. blakei, C. yasguri, Trichodectes canis) the introduction dates back to the 1990s, the first years of operating a quarantine station in Iceland. It seems likely that treatment against the parasites failed for some unknown reasons.

In 1992 the demodectic mange mite $D$. canis was found to infest an 8 month-old bulldog that a few weeks earlier had finished a stay in a quarantine station and had been delivered to its owner (Skírnisson \& Finnsdóttir 1993). At present $D$. canis infestations (Figure 4) are regularily observed on bulldogs and pugs in Iceland (Helga Finnsdóttir, pers. com.).

Only limited data are available on the presence and distribution of the canine nasal mite $P$. caninum in Iceland. It was first observed and subsequently photographed at the Animal Hospital in Garðabær in 2012, during rhinoscopy of a five-year-old dog that suffered from nasal discharge and sneezing (Hanna María Guðmundsdóttir, pers. com.). No mites were submitted to Keldur for detailed examination. However, morphological features noticed on the photograph taken during the rhinoscopy and the predilection site of the mite in the nasal sinuses support the view that the mite was $P$. caninum. 
Two Cheyletiella species, (often referred to as walking dandruff) were first detected in Iceland in the 1990s. C. yasguri is a dog parasite. The mite was first identified in 1996 and 1997 as it was found in samples from dogs living in six separate homes in the Reykjavík capital area (Figure 3). A few years later dogs in a distant kennel were also found to be infested with the mite. At present veterinarians working in pet clinics in the Reykjavík area notice a few Cheyletiella infestations on dogs every year (Halldóra Hrund Guðmundsdóttir, pers. com). C. blakei was confirmed in Iceland in 1995, on two young Persian cats originating from a breeder that had recently imported Persian cats through a quarantine station. The mite (at the time erroneously identified as C. parasitivorax) was found on the cats after the owners had developed signs of allergic reaction on arms and trunk soon after holding the cats in their arms (Skirnisson et al. 1997). Anti-ectoparasitic treatment was apparently effective and since then $C$. blakei has not been identified in Iceland.

In 1992 the canine chewing louse T. canis was confirmed on dogs in a small kennel soon after having brought an imported dog, apparently infested with the parasite, to the kennel (Richter et al. 1993). Anti-ectoparasitic treatment of dogs in the kennel seemed to have been effective, as since then this chewing louse has not been reported in Iceland again.

Probably in 2009 the zoonotic nematode $S$. stercoralis (Figure 1) is believed to have been introduced with an imported dog to a kennel in Iceland which housed roughly $200 \mathrm{dogs}$, in spite of the required anthelmintic treatments during quarantine. At this time, however, the additional treatment, specific against $S$. stercoralis performed nowadays during quarantine, was not done. In 2012 faecal examinations confirmed that approximately half of the dogs in the kennel had a $S$. stercoralis infection. In addition, some household dogs recently purchased from the kennel were found to be infected, and dogs that had been in contact with infected dogs from the kennel had also acquired the infection. Intensive search for infected dogs, and repeated, systematic anthelmintic treatments, were

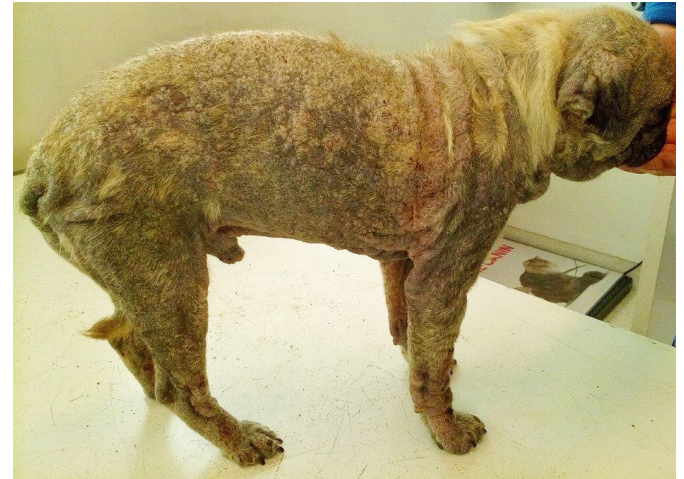

Figure 4. Icelandic pug severely infested with the demodectic dog mite Demodex canis. Photograph: Helga Finnsdóttir.

carried out. Follow-up studies indicate that S. stercoralis had already been eradicated in Iceland in 2015 (Eydal \& Skirnisson 2016). No infected dogs have now been detected in Iceland for two and a half years.

\section{Sporadic introduction of ectoparasites into Iceland}

In recent decades human activities are considered to have been responsible for the introduction of four pet ectoparasites into Iceland. The species are the $\operatorname{dog}$ tick $R$. sanguineus, the cat mallophagan F. subrostratus, the dog louse $L$. setosus, and the flea $C$. felis. When detected there has been an awareness leading to proper treatment of the infested hosts and their surroundings with effective drugs in order to eliminate the infestations.

The brown $\operatorname{dog}$ tick $R$. sanguineus is known to have been introduced with humans to Iceland on several occasions in past decades. In 2005 an endophilic population developed on a single dog for almost half a year, before the ticks were eliminated using acaricides (Skírnisson \& Eydal 2008). In this case the tick was believed to have originated in Germany, from where it was transported in luggage. In 2010 the brown dog tick was collected from a dog in another home in the Reykjavík area, and in 2017 ticks were again detected on dogs in two distinct households. Humans recently travelling abroad were, in all cases, believed to have accidentally transported 
the ticks to the homes of the dogs which later became infested.

It remains unknown when and how the cat chewing louse $F$. subrostratus was brought to Iceland. This mallophagan was first detected on cats in Reykjavík in 1969, later also in 1973. In 1990 it was again diagnosed from cats from three different sites in Southwest Iceland (Skirnisson \& Richter 1992). Since then no cases have been identified at Keldur and some practicing veterinarians questioned about this easily observed parasite have not noticed the louse. Therefore, we believe that the cat chewing louse does not infest cats in Iceland at present.

The sucking louse of dogs L. setosus was first reported in 1989 from dogs in a household in Reykjavík. Several months earlier a foreign pet groomer visited Iceland and clipped the coat of the dogs in connection with a dog exhibition in the Reykjavík area. It was suggested that equipment imported and used by the dog groomer carried nits or lice into the country (Eydal 1992b). Almost two decades later the dog sucking louse was again identified at Keldur from dogs in three distinct households in different parts of the Reykjavík area. Surprisingly, all the cases were identified in January 2007. Whether these cases were interconnected remains unknown. Since then, however, this quite easily recognizable parasite has not been brought to Keldur for identification and practicing veterinarians questioned about its presence have not detected the parasite (Halldóra Hrund Guðmundsdóttir, Helga Finnsdóttir, pers. com).

Ctenocephalides spp. fleas have occasionally been reported from dogs and cats in Iceland. In 1980 and again in 1984, cat fleas C. felis were identified from dogs in Reykjavík (Skirnisson \& Richter 1992). A single cat flea was identified from a dog in 2004, and in 2016 cat fleas were identified from cats in two homes in different districts of Reykjavík. The origin of these two cases was not clarified. Later in 2016 a cat flea outbreak started on a farm in South Iceland. Several cats and a dog were affected. The owner is believed to have accidentally brought cat fleas to the farm some months earlier when returning to Iceland after a visit to Europe. In all cases, except one, fleas found on dogs and cats in Iceland have been cat fleas $C$. felis. The only exception was the $\operatorname{dog}$ flea $C$. canis, detected on an imported dog in quarantine in 2012.

\section{Native ectoparasites}

The ear canker mite O. cynotis is permanently present in Iceland and known to frequently infest cats (Skirnisson \& Richter 1992, Ágústsson \& Richter 1993). The mite has also been reported from dogs (Lohse 2001) and farmed foxes (Gunnarsson et al. 1991). Farmed silver foxes (Vulpes vulpes) imported in the 1930s from Norway were known to be infested with the mite, as well as foxes that were imported in 1983 from Norway when a temporary ban of fur farming in Iceland had been lifted. An extensive study on the geographical distribution of the ear canker mite in the arctic fox revealed that $38 \%$ of foxes from a single county in northwestern Iceland were infested (Gunnarsson et al. 1991).

The common chewing louse of cattle Bovicola bovis is occasionally detected on dogs on cattle farms in Iceland (Eydal \& Richter 2010), though mainly on puppies that have been in close contact with infested calves (Eydal 1992b). Also, the mesostigmatan mite Cyrtolaelaps mucronatus, a free-living predatory mite, sometimes occurs in high numbers in cat's beds and is found to adhere to the coat (Skirnisson \& Richter, 1992). The red poultry mite $D$. gallinae is a native parasite of poultry in Iceland (Skirnisson 2017b) and may develop persistent infestations on dogs and cats (Rommel 2000). In one case the mite was detected in a quarantined dog in Iceland.

In past decades the tick I. ricinus has been frequently detected on dogs and cats in Iceland. The ticks are transported to Iceland in the springtime every year with migratory birds (Richter 1981, Richter et al. 2013). A recent field sampling of questing males, females and nymphs in southern and southeastern Iceland indicates that the species could possibly be established locally. However, because questing larvae were not found, established populations in Iceland can not be confirmed (Alfredsson et al. 2017). 


\section{CONCLUSIONS}

Only a small part of the world fauna of dog and cat parasites is found in Iceland. This unique status is determinated by various factors, not least the geographical isolation of Iceland - an island situated in the middle of the North Atlantic Ocean, where relatively small and isolated populations of dogs and cats have existed through the centuries. Various measures and local conditions contributed to the successful eradication of the dreadful cestodes E. granulosus and Taenia multiceps. Other parasites, temporarily occurring in Iceland in recent decades, have also been eliminated. These are the nematode $S$. stercoralis and six ectoparasite species (C. blakei, R. sanguineus, F. subrostratus, L. setosus, T. canis and C. felis). However, at the same time at least two dog mites (D. canis, C. yasguri) and most probably also the nasal dog mite $P$. caninum have been introduced and still infest dogs in Iceland, in many instances with severe consequences for the health and welfare of the affected dogs. Interestingly, the ectoparasites that have not been eliminated in Iceland are all mite species. Those successfully eliminated include a tick ( $R$. sanguineus), three mallophagans (F. subrostratus, L. setosus, T. canis) and two flea species (C. canis, $C$. cati). This situation has been achieved by clear legislation, effective restrictions, strong surveillance and the systematic use of effective antiparasitic drugs.

Unique circumstances enable Icelanders to control imports into the island and fight and hinder introduction of new parasites. In spite of the exceptions mentioned above (the three mite species) this campaign has, so far, been quite successful. And this success should encourage Icelandic authorities to continue the ongoing control. Dozens of canine and feline parasites, still absent in Iceland, some of them zoonotic species, occur in/on dog and cat populations in other countries of the world. If introduced, some of these parasites may severely affect the health and welfare of dogs, cats and even humans in Iceland.

\section{ACKNOWLEDGEMENTS}

A number of pet owners, veterinarians and personnel working at the quarantine stations in Hrísey and Hafnir have collaborated with the authors in past decades. Five practicing veterinarians, Halldóra Hrund Guðmundsdóttir, Hanna María Guðmundsdóttir, Helga Finnsdóttir, Jakobína Björk Sigvaldadóttir and Katrín Harðardóttir, kindly informed the authors about the occurrence of dog and cat ectoparasites in Iceland in recent years. Sincere thanks to all of you for valuable help. Special thanks are owed to our former colleague Sigurour H. Richter, who started examinations on dog and cat parasites soon after starting working with parasites at Keldur in the early 1970 s.

\section{REFERENCES}

Ágústsson P \& Richter SH 1993. Sníkjudýr í og á köttum í Reykjavík og nágrenni. [Ecto- and endoparasites of cats in the Reykjavík area]. Dýralceknaritið 8, 24-29. [In Icelandic with English summary].

Alfredsson M, Olafsson M, Eydal M, Unnsteinsdottir ER, Hansford K, Wint W, Alexander N \& Medlock JM 2017. Surveillance of Ixodes ricinus ticks (Acari: Ixodidae) in Iceland. Parasites \& Vectors 10:466. http://dx.doi.org/10.1186/s13071-017-2375-2

Allen AV \& Ridley DS 1970. Further observations on the formol-ether concentration technique for faecal parasites. Journal of Clinical Pathology 23, $545-546$.

Anonymous 1986. Manual of Veterinary Parsitological Laboratory Techniques. Reference Book 418. Ministry of Agriculture, Fisheries and Food. London. Her Majesty's Stationery Office. $160 \mathrm{p}$.

Ash L \& Orihel T 1997. Atlas of Human Parasitology. 4th edn. American Society of Clinical Pathologists, Chicago, Illinois, $410 \mathrm{p}$.

Barr SC \& Bowman DD 2012. Blackwell's FiveMinute Veterinary Consult Clinical Companion: Canine and Feline Infectious Diseases and Parasitology, Second edition. John Wiley \& Sons, $634 \mathrm{p}$.

Beard TC 1973. The elimination of echinococcosis from Iceland. Bulletin of the World Health 
Organisation 48, 653-660.

Beaver PC, Jung RC, Cupp EW \& Craig CF 1984. Clinical Parasitology. 9th edn. Lea \& Febiger, Philadelphia, $825 \mathrm{p}$.

Bowman DD 2009. Georgis' Parasitology for Veterinarians, 9th edn. Saunders Elsevier, St. Louis, Missouri. 451 p.

Davidson RK, Lavikainen A, Konyaev S, Schurer J, Miller AL, Oksanen A, Skírnisson K \& Jenkins E 2016. Echinococcus across the North: Current knowledge, future challenges. Food and Waterborne Parasitology 4, 39-53. http://dx.doi.org/10.1016/j.fawpar.2016.08.001.

Dungal N 1957. Eradication of hydatid disease in Iceland. New Zealand Medical Journal 56, 212222.

ESCCAP 2017. Worm Control in Dogs and Cats. European Scientific Counsel Companion Animal Parasites Guidline 01, Third Edition. 38 p.

Eydal M, Richter SH \& Skírnisson K 1990. Gródýrið Cryptosporidium og sýkingar af völdum pess. [Infections caused by the coccidian Cryptosporidium in humans in Iceland]. The Icelandic Medical Journal 76, 264-266. [In Icelandic with English summary].

Eydal M 1992a. Breiðibandormur finnst í hundi. [Diphyllobothrium sp. detected in a dog]. Dýralceknaritið 7, 27-29. [In Icelandic].

Eydal M 1992b. Hundalús finnst á Î́slandi. [Linognatus setosus found in Iceland]. Dýralceknaritid 7, 30-31. [In Icelandic].

Eydal M, Richter SH \& Skirnisson 2001. Parasites of imported dogs and cats in Iceland 19892000. Bulletin of the Scandinavian Society for Parasitology 11, 31-32.

Eydal M \& Jörundsson E 2017. Vöðvasullur greinist á ný í sauðfé. [Taenia ovis detected again in sheep]. The Icelandic Medical Journal 103, Supplement 91, 87. [In Icelandic].

Eydal M \& Richter SH 2010. Lice and mite infestations in cattle in Iceland. Icelandic Agricultural Sciences 23, 87-95.

Eydal M \& Skírnisson K 2016. Strongyloides stercoralis found in imported dogs, household dogs and kennel dogs in Iceland. Icelandic Agricultural Sciences 29, 39-51.

Finnsdóttir H 1997. Tíðni mótefna gegn bogfrymlasótt í blóði katta á Íslandi. [Prevalence of antibodies agains Toxoplasma gondii in sera of
Icelandic cats]. Dýralceknaritið 1997, 16-21. [In Icelandic].

Gunnarsson E, Hersteinsson P \& Aðalsteinsson $S$ 1991. Prevalence and geographical distribution of the ear canker mite (Otodectes cynotis) among arctic foxes (Alopex lagopus) in Iceland. Journal of Wildlife Diseases 27, 105-109.

Henriksen SA 1965. En forbedret teknik ved undersøgelser for lungeormelarver $i$ faeces. [An improved technique for the examination of faeces for larvae of lungworms]. Nordisk Veterincermedicin 17, 446-454. [In Norwegian].

Krabbe H 1865. Helmintologiske Undersøgelser i Danmark og paa Island med særligt Hensyn til Blæreormlidelserne paa Island. [Helminth investigation in Denemark and Iceland with a special reference to the echinococcosis problem in Iceland]. Det Kongelige Danske Videnskabernes Selskabs Skrifter 5, 1-71. [In Danish].

Lohse JE. 2001. Molekularbiologische Untersuchungen zur Taxonomie von Ohrmilben der Gattung Otodectes (Acari: Psoroptidae). [Molecular investigation on the taxonomy of the ear canker mite Otodectes (Acari: Psoroptidae)] Thesis. Univerität München. 94 p. [In German].

Miyazaki I 1991. An Illustrated Book of Helminth Zoonoses. International Medical Foundation of Japan, Tokio, $494 \mathrm{p}$.

MAST 2018. Innflutningur hunda og katta (Import of dogs and cats) http://www.mast.is/innogutflutningur/dyr/innflutningur-hunda-og-katta/ [In Icelandic].

Pálsson PA 1976. Echinococcosis and its elimination in Iceland. Historia Medicinae Veterinariae 1, 4-10.

Pálsson PA 1984. Hydatidosis in Iceland: how it was eradicated. In: Euzeby J \& Gevrey J (eds). Some important parasitic infections in bovines considered from economic and social (zoonosis) points of view, Parasitological symposium, Lyons, France, 24-26 October, 1983, pp. 121-131.

Pálsson PA, Sigurðsson B \& Hendriksen K 1953. Sullaveikin á undanhaldi. [Echinococcosis disappearing in Iceland]. Loeknablaðið 37, 1-13. [In Icelandic].

Pálsson PA, Vigfússon H \& Henriksen K 1971. Heldur sullaveikin velli? [Is echinococcosis disappearing in Iceland?]. Laeknablaðið 57, 39-51. [In Icelandic]. 
Richter SH 1981. Ixodes ricinus á Islandi [Ixodes ricinus in Iceland]. Dýralceknaritið 2, 14-17. [In Icelandic with English summary].

Richter SH \& Elmarsdóttir Á 1997. Intestinal parasites in dogs in Iceland: The past and the present. Icelandic Agricultural Sciences 11, 151158.

Richter SH, Eydal M \& Sigurðarson S 1984. Taenia (Cysticercus ovis). Nýr sullur í sauðfé á Íslandi. [Taenia (Cysticercus ovis). Sheep measles reported in Iceland]. Freyr 80, 658-661. [In Icelandic].

Richter SH, Eydal M \& Sigurðarson S 1987. Útbreiðsla vöðvasulls. [Distribution of Taenia (Cysticercus ovis) in Iceland]. Freyr 83, 191-193. [In Icelandic].

Richter SH, Eydal M, Skírnisson K \& Ólafsson E 2013. Tick species (Ixodida) identified in Iceland. Icelandic Agricultural Sciences 26, 3-10.

Richter SH, Skírnisson K \& Eydal M 1993. Sníkjudýr í og á innfluttum hundum og köttum. [Parasites of imported dogs and cats in Iceland]. Dýralceknaritið 8, 18-23. [In Icelandic with English summary].

Rommel M, Eckert J, Kutzer E, Körtling W \& Schnieder $\mathbf{T}$ 2000. Veterinärmedicinische Parasitologie. Parey, Berlín. 915 p.

Skírnisson K 2017a. Bandormafána landspendýra á Íslandi að fornu og nýju. [On the cestode fauna of terrestrial mammals in Iceland]. Náttúrufrceðingurinn 87, 116-131. [In Icelandic with English summary].

Skírnisson K 2017b. Нvað er vitað um rauða hænsnamítilinn (Dermanyssus gallinea) á Íslandi? [What is known about Dermanyssus gallinea in Iceland?]. https://www.visindavefur.is/svar. php?id=73932 [In Icelandic].

Skírnisson K \& Eydal M 2008. Blóðsjúgandi hundamítlar berast til Íslands. [Bloodsucking dog ticks detected in Iceland]. Náttúrufrceðingurinn 77, 53-57. [In Icelandic with English summary].

Skírnisson K, Eydal M, Gunnarsson E \& Hersteinsson P 1993. Parasites of the arctic fox Alopex lagopus in Iceland. Journal of Wildlife Diseases 29, 440-446.

Skírnisson K, Eydal M \& Richter SH 1993. Gródýr af ættkvíslinni Cryptosporidium í dýrum á Íslandi. [Cryptosporidium spp. in animals in Iceland]. Dýralceknaritið 8, 4-13. [In Icelandic with English summary].
Skírnisson K \& Finnsdóttir H 1993. Hársekkjamaurinn Demodex canis finnst á hundi hér á landi. [Demodex canis reported from an Icelandic dog]. Náttúrufrceðingurinn 63, 38. [In Icelandic].

Skírnisson K, Jouet D, Ferté H \& Nielsen OK 2016. Occurrence of Mesocestoides canislagopodis (Rudolphi, 1810) (Krabbe 1865) in mammals and birds in Iceland and its molecular descrimination within the Mesocestoides species complex. Parasitology Research 115, 2597-2607.

DOI 10.1007/s00436-016-5006-5

Skírnisson K, Ólafsson JH \& Finnsdóttir H 1997. Um Cheyletiella-maurakláða á mönnum og köttum á Íslandi. [Dermatitis in cats and humans caused by Cheylatiella-mites reported in Iceland]. The Icelandic Medical Journal 83, 30-34. [In Icelandic with English summary].

Skírnisson K \& Richter SH 1992. Óværa á köttum. [Ectoparasites of cats]. Dýralceknaritið 7, 3-8. [In Icelandic].

Sloss MW 1972. Veterinary Clinical Parasitology. 4th ed. The Iowa State University Press, Ames. $250 \mathrm{p}$.

Smáradóttir H \& Skírnisson K 1996. Um katta- og hundasníkjudýr í sandkössum. [Zoonotic parasites of cats and dogs found in play-ground sandboxes in the Reykjavík area, Iceland]. The Icelandic Medical Journal 82, 627-634. [In Icelandic with English summary].

Soulsby EJL 1965. Textbook of Veterinary Clinical Parasitology, Vol. 1. Helminths. Oxford, Blackwell Scientific Publications. 1120 p.

Thienpoint D, Rochette F \& Vanparijs OFJ 1979. Diagnosing helminthiasis through coprological examinations. Jassen Research Foundation, Belgium. $187 \mathrm{p}$.

Taylor MA, Coop RL \& Wall RL 2007. Veterinary Parasitology. 3rd ed. Oxford, Blackwell Publishing Ltd., 904 p.

Young KH, Bullock SL, Melvin D \& Spruill CL 1979. Ethyl acetate as a substitute for diethyl ether in the formalin-ether sedimentation technique. Journal of Clinical Microbiology 10, 852-853.

Manuscript received 28 March 2018 Accepted 28 June 2018 